\section{СВЕТОТЕХНИЧЕСКАЯ УСТАНОВКА}

С ИЗЛУЧЕНИЕМ

В УФ- И ВИДИМОМ

ДИАПАЗОНАХ СПЕКТРА

\section{ДЛЯ СЕЛЬСКОХОЗЯЙСТВЕННОЙ пТИЦЫ}

Коваленко О.Ю., д.т.н., Пильщикова Ю.А. к.т.н,, Гусева Е.Д., аспирант, Мордовский государственный университет им. Н.П. Огарева, Саранск

В статье рассмотрены вопросы разработки и совершенствования энергосберегающих и биологически эффективных светотехнических установок для птицеводства. Показано, что при использовании системы общего и местного освещения и облучения сине-зелеными светодиодными кластерами и ультрафиолетовыми лампами в разработанной светотехнической установке обеспечивается совершенствование светоцветовой среды в птичнике, что способствует повышению показателей продуктивности сельскохозяйственной птицы и экономической эффективности применения светотехнических установок.

еализация Государственной программы развития сельского хозяйства на 2013-2020 годы предусматривает стимулирование роста производства основных видов сельскохозяйственной продукции, в том числе продукции птицеводства. Поэтому решение вопросов разработки и совершенствования энергосберегающих и биологически эффективных светотехнических установок для птицеводства весьма актуально.

Основные технические требования, предъявляемые к облучательным светотехническим установкам (ОСУ), и необходимые в расчете параметры определяются назначением установки. При этом для всех установок необходимо учитывать:

- характеристики приемника оптического излучения (спектральная и интегральная чувствительность приемника, временная зависимость реакции приемника от излучения);

- требования по производительности (количественные и качественные характеристики конечного продукта на единицу мощности);
LIGHTING FACILITY WITH RADIATION

\section{IN UV AND VISIBLE SPECTRAL RANGES FOR POULTRY}

\author{
O.Yu.Kovalenko, Dr. of Science (Engineering), \\ Yu.A.Pilshchikova, Ph.D. (Engineering), \\ E.D.Guseva, Ph.D. student, \\ Mordovia State University named by N.P.Ogarev, \\ Saransk
}

The issues of development and improvement of energy-saving and biologically-efficient lighting facilities for poultry farming are considered in the article. It is shown that in case of use of the system of general illumination and local illumination and irradiation from blue-green light emitting diode clusters and ultraviolet lamps in developed lighting facility, the improvement of light and color environment in poultry house is provided, and this fact enhances the parameters of poultry productivity and economical efficiency of use of lighting facilities.

mplementation of the State Program for Agriculture Development for the period 2013-2020 provides the stimulation of production growth of the main types of agricultural products, including the products of poultry farming. Therefore, the solution of issues connected with development and improvement of energy-saving and biologicallyefficient lighting facilities for poultry farming is very relevant.

The main technical requirements specified for irradiation lighting facility (ILF) and parameters used in calculations are determined by the intended purpose of facility. Further, it is necessary to take into account the following:

- Characteristics of detector of optical radiation (spectral and integrated sensitivity of detector, time dependence of detector response on radiation);

- Requirements to productivity (quantitative and qualitative characteristics of finished product per unit of power);

- Operational conditions (climatic conditions, environmental characteristics);

- Construction and technological requirements (power source, service life, reliability, requirements to protection against electric 
- условия эксплуатации (климатические условия, характеристики окружающей среды);

- конструктивно-технологические требования (источник питания, срок службы, надежность, требования к защите от поражения электрическим током, требования к управлению, монтажно-эксплуатационные требования, технологические режимы облучения);

- требования к технико-экономическим характеристикам (величина капитальных затрат, эксплуатационных расходов, срок окупаемости).

Разработанная и предллагаемая к использованию новая осветительная установка ОСУ предназначена для облучения сельскохозяйственной птицы. Приемник излучения в данном случае кожа и органы зрения птицы. Основные спектральные характеристики приемника определяются спектральной чувствительностью этих органов. Осу была разработана на базе источников излучения в УФ- и видимом диапазонах спектра (рис.1).

Устройство (облучатель) содержит корпус 1, отражатель 2, четыре петли 3 для подвеса облучателя. В верхней части отражателя 2 находится прямоугольное отверстие 4. На нижнем основании корпуса 1 выполнена отбортовка 5. На отбортовке 5 по периметру выходного отверстия корпуса 1 закреплены отражатели 6, световые отверстия которых ориентированы вниз. В фокальной плоскости каждого из отражателей 6 установлены две эритемные лампы 7. На верхнем основании корпуса 1 во внутренней полости установлены две бактерицидные лампы 8. Каждая пара ламп $(7,8)$ для подключения к питающей электросети снабжена стандартной электротехнической арматурой и дросселями (драйверами) 9, закрепленными на металлическом профиле 10. На металлическом профиле 10 установлен модуль 11 с расположенными на нем синими и зелеными светодиодами 12, снабженными электротехнической арматурой и драйверами 9. Разработанное устройство и его принцип действия подробно описаны в работе [1].

Был изготовлен опытный образец устройства и проведены измерения его основных параметров. Измерения кривых силы излучения от всех групп ламп и светодиодов проводились на фотометрической скамье с помощью приемников УФ- и видимого излучения по стандартной методике.

В облучателе в качестве бактерицидных ламп использовались источники ультрафиолетового облучения области С (УФС) типа ДБМ-15, в качестве эритемных ламп - источники ультрафиолетового излучения области В и С (УФВ, УФС) типа ЛЭБ-15. Лампы типа ЛЭБ-15 повышенной эффективности

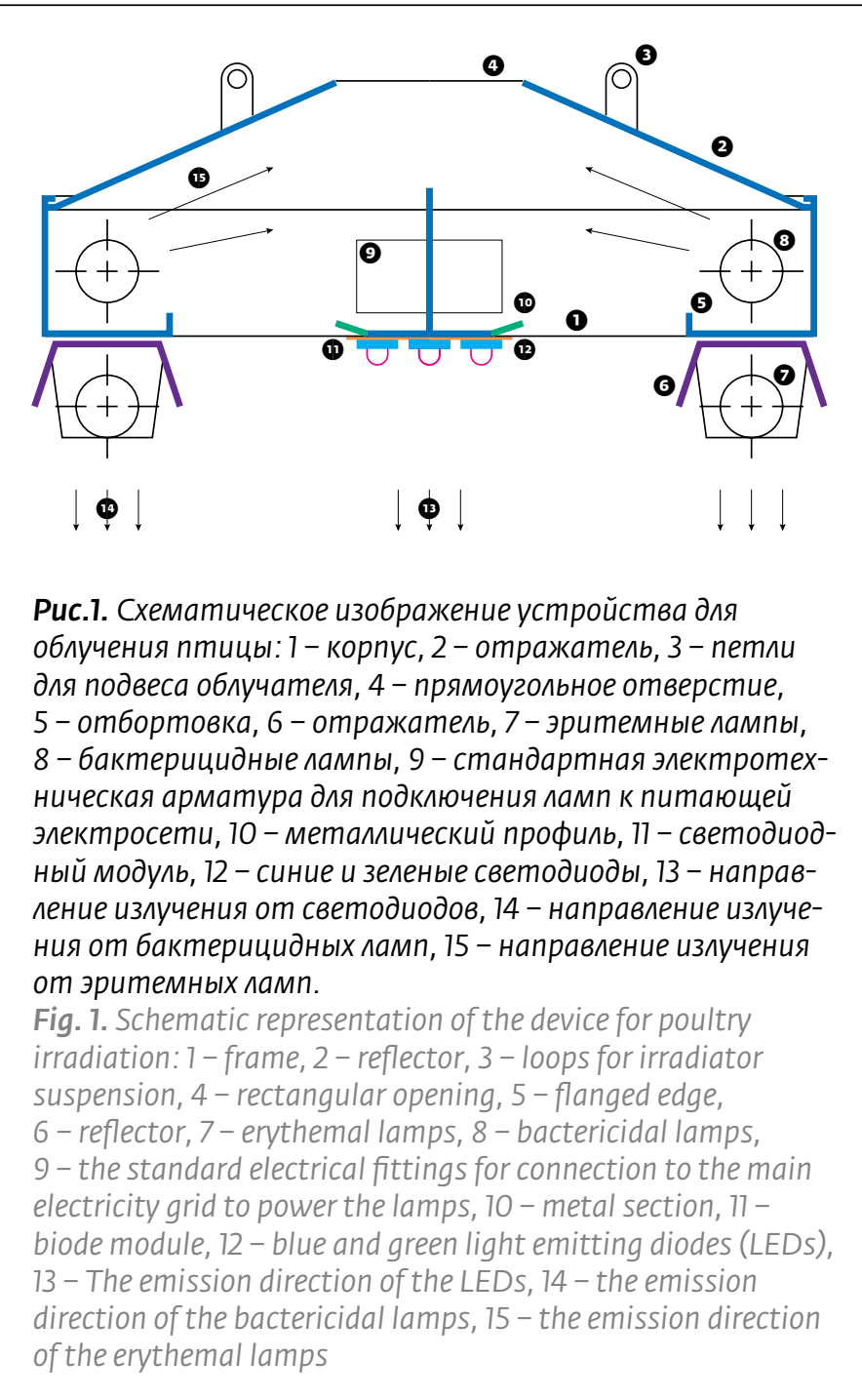

shock hazard, requirements to management, installation and maintenance requirements, technological conditions of irradiation);

- Requirements to technical and economical characteristics (amount of capital expenditures, operational costs, payback period).

In accordance with the specification, ILF is intended for the irradiation of poultry. The main characteristics of radiation detector included the spectral sensitivity of poultry skin and vision organs. ILF was developed on the basis of radiation sources in UV and visible spectral ranges (Fig. 1).

The facility (irradiator) contains: frame 1, reflector 2, four loops 3 for irradiator suspension. The top part of irradiator 2 consists of rectangular opening 4. The lower base of frame 1 has flanged edge 5. Around the perimeter of output of the frame 1 the reflectors 6 , light windows of which are oriented downwards, are secured on flanged edge 5. Two 
отличались от стандартных ламп типа ЛЭ-15 наличием определенной доли излучения УФС, кроме излучения УФВ, при соотношении энергетических потоков $\mathrm{F}_{\text {уФс }}: \mathrm{F}_{\text {Уфв }}=1: 4,2$ [2].

Для проведения испытаний в помещении для выращивания сельскохозяйственной птицыбыли проведены расчеты энергетической освещенности с помощью специально разработанной программы с алгоритмами для одновременного использова ния источников оптического излучения четырех типов [3].

Расчет основывался на определении спектраль ных энергетических освещенностей, приведенных к одним и тем же единицам измерения, в точках рабочей поверхности отдельно для каждого из близкорасположенных источников. Формула для расчета спектральной энергетической освещенности от і-го осветительного прибора (ОП) в точках рабочей поверхности имеет следующий вид:

$$
\AA(\lambda)_{i}=\frac{h \eta^{2}}{\pi K_{3}\left(a_{i}^{2}+h^{2}\right)^{3 / 2}} \sum_{\lambda_{1}}^{\lambda_{2}} F_{i}(\lambda) \Delta \lambda,
$$

где $\mathrm{F}_{\mathrm{i}}(\lambda)$ - спектральный поток излучения от каждого і-го источника, Вт; $\eta, \mathrm{K}_{3}$ - коэффициенты использования и запаса; h - высота подвеса над рабочей поверхностью, м; $\mathrm{a}_{\mathrm{i}}^{-}$расстояния от ОП до расчетной точки в проекции на горизонтальную плоскость, м.

Спектры от каждого из источников суммировались по длинам волн, определялись интегральные значения энергетической освещенности.

Реализация алгоритма осуществлена в среде Delphi. Иллюстрирует работу алгоритма рис.2. В окне 1 производится расчет суммарной энергетической освещенности в любой точке рабочей поверхности с указанием ее координат при щелчке мыши после установки на ней стрелки курсора (рис.2а). В окне 2 программы показывается спектральное распределение облученности в Bт/ $\mathrm{M}^{2}$ от действия четырех источников излучения (рис.2b).

Расчет осу с экспериментальными облучателями для излучения в области УФВ и УФС был проведен с использованием программы [4, 5].В результате расчета было установлено, что при высоте подвеса 1,8 м средняя облученность области УФВ на уровне спины облучаемой птицы составила

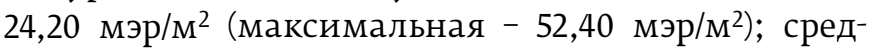
няя облученность области УФС на уровне спины облучаемой птицы составила 12,34 мВт/м² (максимальная - 23,10 мВт/м²). Для перевода эффективной erythemal lamps 7 are installed in the focal plane of every reflector 6 . Two bactericidal lamps 8 are placed on the top base of frame 1 in intracavity. For the purpose of connection to supply network every couple of lamps $(7,8)$ is equipped with the standard electric fixtures and chokes (drivers) 9 fastened on metal section 10 . The module 11 is installed on metal section 10 with blue and green light emitting diodes 12 located on it and equipped with electric fixtures and drivers 9. Developed facility and principle of its operation are described in details in the paper [1].

The prototype of facility was made, and the measurements of its basic parameters were performed. Measurements of curves of radiation intensity from the lamps of all groups and light emitting diodes were performed on photometer bench using the detectors of UV and visible radiation by standard methods.

The sources of ultraviolet radiation of the area C (UVC) of DBM-15 type were used in the irradiator in capacity of bactericidal lamps; the sources of ultraviolet radiation of the areas B and C (UVB, UVC) of LEB-15 type were used in the capacity of erythemal lamps. The lamps of LEB-15 with higher efficiency differed from the standard lamps of LE-15 type by the presence of certain portion of UVC radiation, except for UVB radiation, with the ratio of energy flow $\mathrm{F}_{\mathrm{UVC}}: \mathrm{F}_{\mathrm{UVB}}=1: 4.2[2,3]$.

In order to carry out the tests in the premises for poultry breeding, the calculations of irradiance were performed using the special developed program with algorithms for simultaneous use of optical radiation sources of four types [4].

Calculations were based on the determination of spectral irradiances brought to the same measurement units, at the points of operating surface separately for every closely-spaced source. Formula for the calculations of spectral irradiance from the $i^{\text {th }}$ irradiation device (ID) at the points of operating surface has the following form:

$$
\AA(\lambda)_{i}=\frac{h \eta^{2}}{\pi K_{3}\left(a_{i}^{2}+h^{2}\right)^{3 / 2}} \sum_{\lambda_{1}}^{\lambda_{2}} F_{i}(\lambda) \Delta \lambda,
$$

where $F_{i}(\lambda)$ - spectral radiation flux from $i^{\text {th }}$ source, $\mathrm{W} ; \eta, \mathrm{K}_{3}$ - coefficients of use and reserve; $\mathrm{h}$ - height of suspension above the operational surface, $\mathrm{m} ; \mathrm{a}_{\mathrm{i}}-$ distance from ID to reference point in projection to horizontal plane, $\mathrm{m}$.

Spectrums from every source were summed up by wavelengths; the integral values of irradiance were determined. 


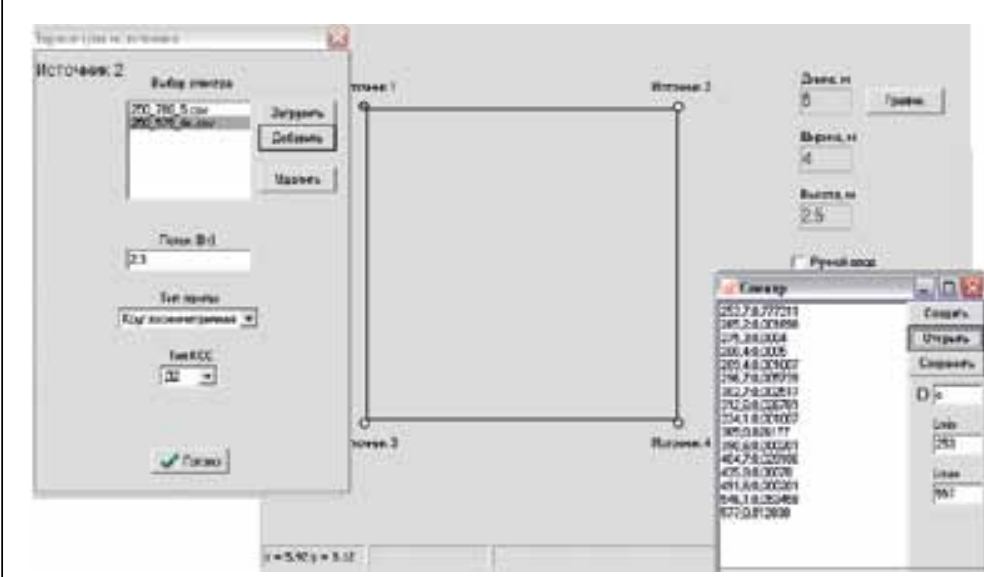

a)

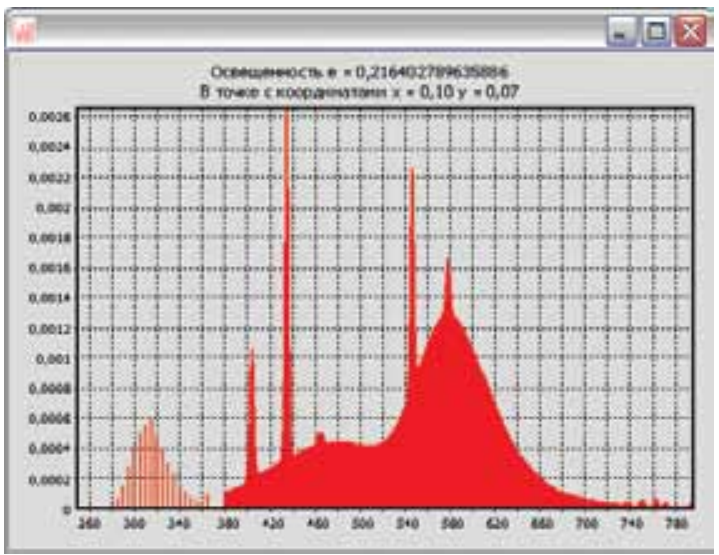

b)

Puс.2. Окна программы расчета спектрального распределения энергетической освещенности: a) - рабочее окно программы с окнами ввода входных параметров и фрагмента рабочей поверхности с указанием его координат; b) - окно с изображением расчетного спектрального распределения освещенности, создаваемой лампами типа ЛБ, синими и зелеными светодиодами и ультрафиолетовым источником излучения

Fig. 2. Windows of the program for calculation of spectral distribution of irradiance: a) - active window of the program with the windows of input of input parameters and fragment of operational surface; $b$ ) - window with the display of calculated spectral distribution of irradiance generated by the lamps of LB type, blue and green light emitting diodes and ultraviolet radiation source

эритемной облученности из мэр/ $\mathrm{M}^{2}$ в $\mathrm{MBT} / \mathrm{M}^{2}$ для ламп типа ЛЭ 15 , ЛЭБ 15 в соответствии со спектром эритемной эффективности, представленным в ГОСТ МЭК 60335-2-27-2009, необходимо использовать множитель 1,25.

Спектр излучения, полученный с помощью разработанной установки и установки с осветительными люминесцентными лампами типа ЛБ 40, соответствовал спектральной эритемной эффективности и спектральной чувствительности органа зрения птицы, что является необходимым условием повышения эффективности светотехнических установок [6].

При оценке эффективности разработанной Осу в производственных условиях были исследованы следующие показатели: прирост живой массы, сохранность поголовья, выход яиц на несушку, а также проведен расчет экономической эффективности. Одним из важных показателей продуктивности также является однородность стада, характеризуемая выравненностью стада по живой массе. Однородность является одним из наиболее эффективных технологических приёмов повышения продуктивности птицы, позволяет регулировать физиологическое развитие птицы в раннем возрасте в соответствии с разработанными стандартами, которые значительно ниже генетического потенциала птицы, позволяет судить о воспроизводящих функциях петушков и яичной продуктивности кур-несушек, оказывает влияние на сохран-
Algorithm implementation was performed in Delphi medium. In the window 1 the calculation of total irradiance at any point of operational surface is performed with the indication of its coordinates by mouse click after the arrow cursor is set on it (Fig. 2a). In the window 2 of the program the spectral distribution of irradiance is displayed in $\mathrm{W} / \mathrm{m}^{2}$ due to the action of four radiation sources (Fig. 2b).

Calculation of ILF with experimental irradiators for the purpose of radiation in the areas UVB and UVC was performed using the program [5, 6]. As a result of calculation, it was established that at the suspension height of $1.8 \mathrm{~m}$ the average irradiance of UVB area at the level of backs of illuminated birds was $24.20 \mathrm{mer} / \mathrm{m}^{2}$ (maximum - $52.4 \mathrm{mer} / \mathrm{m}^{2}$ ); average irradiance of UVC area at the level of backs of illuminated birds was $12.34 \mathrm{~mW} / \mathrm{m}^{2}$ (maximum $23.1 \mathrm{~mW} / \mathrm{m}^{2}$ ). It order to convert the efficient erythemal irradiance from $\mathrm{mer} / \mathrm{m}^{2}$ into $\mathrm{mW} / \mathrm{m}^{2}$ for the lamps of LE 15, LEB 15 type in accordance with the spectrum of erythemal efficiency given in COST MEK 60335-2-27-2009 it is required to use the factor 1.25 .

The radiation spectrum obtained with the help of developed facility and facility with illumination luminescent lamps of LB 40 type corresponded to the spectral erythemal efficiency and spectral sensitivity of poultry vision organs, and it is the necessary condition for the enhancement of efficiency of lighting facilities [7]. 
ность птицы.Однородность можно рассчитать с помощью коэффициента вариации, который определяется делением стандартного отклонения по живой массе на среднюю живую массу.

Для оценки влияния спектрального состава осу с ультрафиолетовыми лампами и сине-зеленым светодиодным кластером на молодняк птицы в производственных условиях был проведен опыт. Из суточных ремонтных курочек и петушков промышленного стада кросcа "Ross 308" в каждом опыте методом аналогов сформировали по две группы контрольную (базовую) и опытную. Условия микроклимата птичника были оптимальными. До прибытия суточных цыплят в птичник помещение за 2-3 дня было прогрето, температура пола поддерживалась не ниже температуры в помещении во избежание переохлаждения цыплят. Контроль температуры осуществлялся по показаниям термометров. У молодняка отмечалась хорошая подвижность, активное поедание корма, стадо равномерно распределялось по площади помещения, отсутство вал птичий шум, что говорит о нормальной температуре птичника. Влажность первые 2-3 недели поддерживалась на уровне 70\%, с четвертой недели составила $60 \%$. Уровень относительной влажности регулировался с помощью отопительной системы и вентиляции. В птичнике для поддержания в нем поступления свежего воздуха в необходимых объ емах и для снижения респираторных заболеваний применялась вентиляция. Условия содержания птицы контрольных и опытных групп были одинаковыми и обеспечивались в соответствии с руководством [7]. Птица выращивалась в закрытом птичнике для оптимального контроля над половым созреванием. В темноте интенсивность освещения не превышала 0,5 люкс. В контроль ном (базовом) варианте для общего освещения использовали люминесцентные лампы типа ЛБ 40, в опытном варианте в дополнение к люминес центному освещению применяли разработанную установку с ультрафиолетовыми лампами и сине зелеными кластерами. Для опытных групп за счет применения местного освещения значение освещенности было в среднем на 7 лк выше. Выбор режима освещения был также основан на реко мендациях фирмы - производителя птицы. Режим облучения: эритемные лампы включали один раз в сутки в 8:30 на 15 мин до достижения 14-дневного возраста; два раза в сутки в 8:30 и 13:00 на 15 мин., начиная с 14-дневного возраста; бактерицидные лампы включали 2 раза в сутки в 8:30 и 13:00 на 1,5 ч до достижения 14-дневного возраста, а начиная с 14-дневного возраста время одного облучения уве-
When evaluating the efficiency of developed ILF under industrial conditions, the following parameters were studied: body weight gain, safety of livestock, egg yield per laying bird, and the calculation of economic efficiency was performed. The uniformity of stock is one of the major parameters of productivity; it is characterized by the stock uniformity by body weight. Uniformity is one of the most efficient technological methods of improvement of poultry productivity; it allows regulating the physiological development of birds at early age in accordance with developed standards, which are significantly lower than the genetic potential of birds; it allows estimating the reproductive functions of cockerels and egg production of laying hens and influences on the safety of birds. Uniformity can be calculated using the variation coefficient, which is determined on the basis of division of standard deviation in body weight by average body weight.

In order to estimate the influence of spectral structure of ILF with ultraviolet lamps and bluegreen light emitting diode cluster on young birds, the experiment was carried out under industrial conditions. In every test using the analog method, 2 groups were formed (control (basic) and experimental groups) from day old replacement pullets and cockerels of commercial stock of Ross 308 cross. Microclimate conditions of poultry house were optimal. 2-3 days prior to the arrival of day old chicks into poultry house the premises were heated up, the floor temperature was maintained at the level not lower than the temperature in premises in order to avoid the supercooling of chicks. Temperature control was performed by registration of thermometers. Good mobility, active feed eating were observed in young birds; the stock distributed evenly around the area of premises; the bird noise was absent, and all these facts prove the normal temperature of poultry house. During the first 2-3 weeks the humidity was maintained at the level of $70 \%$, on the fourth week it was $60 \%$. The level of relative humidity was regulated with the help of heating system and ventilation. In poultry house for the purpose of supply of required quantity of fresh air and in order to decrease the level of respiratory diseases, the ventilation was used. Conditions for maintenance of birds from control and experimental groups were identical and provided in accordance with the guidance [8]. Birds were grown in closetype poultry house for the optimal control of puberty. In darkness the illumination intensity did not exceed 0.5 lux. In control (basic) variant the luminescent lamps of LB 40 type were used for 
личивали с 1,5 до 2 ч. При местном освещении светодиодами использовался следующий режим: 1-е сутки - 24 ч; 2-е сутки - 23 ч; 4-10-е сутки - 20 ч; 11-е - сутки и далее - 8 ч.

В исследованиях учитывали и определяли следующие показатели: входные параметры - доза и время облучения, выходные- однородность стада, сохранность поголовья, яйценоскость на среднюю несушку, выход яиц, живая масса птиц.

Для получения указанных показателей в будущем вес птицы в ранний период развития должен быть не ниже, а даже и выше целевого значения веса. В этот период происходит формирование скелета, который в дальнейшем сохраняется практически на весь период жизни, закладывается основа будущей продуктивности стада. Негативным воздействием на вес птицы оказывает стресс, который создается при ряде факторов, таких как каннибализм (расклев птицами друг друга), безвыгульное содержание больших групп. Продуктивный потенциал птицы во многом закладывается во время выращивания, поэтому этот период чрезвычайно важен, но не меньшее значение имеет кривая привесов, предшествовавшая этому моменту и кондиции птицы в этом возрасте. Задача выращивания - позволить птице развиваться точно по плану, general illumination, and in experimental variant developed facility with ultraviolet lamps and bluegreen clusters was used in addition to luminescent lighting. For experimental groups, at the expense of use of local illumination the value of illuminating intensity was by 7 lux higher at the average. Selection of illumination conditions was also based on recommendations of the firm - producer of poultry. Irradiation conditions: erythemal lamps were turned on once a day at 8:30 am for 15 minutes until 14-days age; two times a day at 8:30 am and 1:00 pm for 15 minutes starting from the age of 14 days; bactericidal lamps were turned on 2 times a day at 8:30 am and 1:00 pm for 1.5 hours until 14-days age, and starting from the age of 14 days the period of one irradiation was increased from 1.5 to 2 hours. Upon local illumination by light emitting diodes the following conditions were used: $1^{\text {st }}$ day 24 hours; $2^{\text {nd }}$ day -23 hours; $4^{\text {th }}-10^{\text {th }}$ day -20 hours; $11^{\text {th }}$ day and further -8 hours.

The following parameters were taken into account and determined in studies: input parameters irradiation dose and time, output parameters uniformity of stock, safety of stock, egg production per average laying bird, yield of eggs, body weight of birds. 
что дает возможность контролировать ее гормональные функции. В свою очередь, гормональные функции определяются не только живой массой в конце выращивания, но в большей степени динамикой привесов. Поэтому одной из задач являлось в первые недели жизни получение веса выше целевого.

Птиц взвешивали еженедельно, однородность стада определялась аналогичным способом для обоих групп. Целевой вес и кривая привесов строилась совместно с сотрудниками птицефабрики.

Опыт 1. Объектом исследования явились суточные курынесушки ремонтного молодняка кросса"Ross 308". Кроссы Ross отличаются быстрым ростом, эффективным потреблением корма и отличной жизнеспособностью. Энергетическая ценность куриного яйца довольно высока. В 100 г желтка куриных яиц содержится 1600 кДж энергии, в 100 г белка - только 214 кДж.

В первую неделю птица кормилась вволю, так как при большой доле корма практически отсутствует конкуренция за него, и птицы имеют практически одинаковые привесы.

В опыте, в отличие от контроля, кривая роста была максимально плавной, не наблюдалось резких и быстрых изменений живой массы. С достижения 105-дневного возраста кур-несушек перевели в другую секцию, и эксперимент продолжался до возраста 210 дней. Уровень яичной продуктивности птицы определялся количеством и качеством яиц, снесенных за первый продуктивный период. Оценка яйценоскости на среднюю несушку (в зарубежной литературе - индекс продуктивности) определялась отношением числа яиц, снесенных стадом за учетный период, к среднему поголовью несушек за тот же период. Результаты однород ности, сохранности, яйценоскости на начальную и среднюю несушку, выход яиц обоих групп представлены в табл. 1 [8].

Проведя сравнительный анализ, можно сделать вывод, что разработанный способ освещения
In order to obtain the specified parameters in future, the bird weight during the early development period should be not lower and even higher than the target value of weight. During this period the formation of skeleton, which afterwards remains practically for the whole period of life, takes place, and the basis of future stock productivity is generated. Stress, which can occur due to a number of factors such as cannibalism (picking of each other by birds), confinement of large groups, has the negative influence on poultry weight. Productive potential of poultry in general is formed during growing and therefore this period is extremely important but the curve of body weight increase preceding this moment and bird conditions at this age also play significant role. The task of growing consists in allowing the birds to develop in accurate accordance with the plan and it grants the opportunity to control hormonal functions. In turn, hormonal functions are determined not only on the basis of body weight at the end of growing but on the basis of dynamics of body weight increase, to a 
и облучения позволяет: повысить однородность промышленного стада ремонтного молодняка на 9\%, сохранность птицы - на 4\%.Опытная группа также отличалась хорошим аппетитом, отсутствовал расклев. Оперение было правильное у обеих групп.

Можно сделать вывод, что освещение по предложенной схеме положительно влияет на продуктивные и физиологические качества ремонтного молодняка кур-несушек. Негативных последствий недостаточного веса удалось избежать в обеих группах, так как в этих группах вес птиц достиг целевого значения, но при контроле наблюдалось значение выше целевого. Это влечет за собой появление высокого процента двухжелтковых яиц, повышенную потребность в корме, снижение общего количества яиц.

Опыт 2. Объектом исследования явились суточные петушки ремонтного молодняка кросса "Ross 308". Особое внимание уделяли контролю живой массы у петухов, поскольку они склонны к быстрому набору веса. От веса зависят физиологические и репродуктивные качества петушков. Результаты опыта показали, что за весь период выращивания 100\%-ная сохранность молодняка наблюдалась только в опытной группе, все возраст- greater degree. Therefore, one of the tasks consisted in the obtainment of the weight, which is higher than the target weight, during the first weeks of life.

The birds were weighed once every week, and the stock uniformity was determined in analogous manner for both groups. Target weight and curve of body weight increase were developed together with the employees of poultry farm.

Experiment 1. Day old laying hens of replacement young stock of Ross 308 cross were the study object. Ross crosses are distinguished by fast growth, efficient feed consumption and excellent viability. Energy value of hen egg is quite high. $100 \mathrm{~g}$ of yolk of hen egg contain $1600 \mathrm{~kJ}$ of energy, $100 \mathrm{~g}$ of white only $214 \mathrm{~kJ}$.

During the first week the birds were fed in abundance because in case of large amount of feed the competition is practically absent, and birds have practically identical body weight increases.

In the experiment, as opposed to control, the curve of growth was smooth as much as possible, the abrupt and rapid variations of body weight were avoided. When laying hens reached the age of 105 days they were transferred to another section, and experiment was continued up until the age of 
ные периоды живая масса птиц в этой группе достигла целевого значения, в отличие от опытной, что имеет важное значение для петушков родительского стада. Результаты исследования представлены в табл. 2.

Среднегодовой экономический эффект на 300 голов составляет 722700 руб. Расчеты показывают, что сохранность и однородность стада позволили снизить себестоимость продукции [9].

Таким образом, при использовании системы общего освещения стандартными люминесцентными лампами наряду с местным освещением и облучением от сине-зеленых светодиодных кластеров и ультрафиолетовых ламп в разработанной светотехнической установке обеспечивается совершенствование светоцветовой среды в птичнике, что способствует повышению показателей продуктивности сельскохозяйственной птицы и экономической эффективности применения светотехнических установок.

\section{ЛИТЕРАТУРА}

1. Пат. 118719 РФ Коваленко О.Ю., Пильщикова Ю.А., Ашрятов А.А., Амелькина С.А., Кудашкина М.В. 27.07.2012.

2. Коваленко О.Ю., Пильщикова Ю.А. Ультрафиолетовые лампы с расширенным спектром излучения. - Фундаментальные и прикладные проблемы физики. Часть II: Материалы Международной научно-технической конференции 28-30 мая 2012, Саранск, 2012, с.4-7.

3. Коваленко О.Ю., Умняшкин А.А. Расчет комбинированного спектра от светотехнической установки для животноводческих помещений. - Материалы V Всероссийской конференции "Фундаментальные и прикладные проблемы физики полупроводников и источников света". - Саранск: Мордов. гос. пед. ин-т, 2007, с.8.

4. Свидетельство на программу № 2005612861 РФ. Программа расчета освещенности в помещении со свободным расположением источников света / Панфилов С.А., Коваленко О.Ю., Захаржевский О.А., Савкина А.В.,
210 days. The level of egg production of birds was determined on the basis of quantity and quality of eggs laid during the first productive period. Evaluation of laying ability per average laying bird (in foreign literature, productivity index) was performed on the basis of ratio of number of the eggs laid by the stock during reference period to the average stock of laying birds for the same period. Results of uniformity, safety, egg laying ability per initial and average laying bird, egg yield for both groups are specified in Table 1 [9].

Having performed the comparative analysis, the conclusion can be drawn that developed method of illumination and irradiation allows enhancing the uniformity of commercial stock from replacement young stock by $9 \%$ and bird safety by $4 \%$. Experimental group also had good appetite; there was no picking. Both groups had correct feathering.

The conclusion can be drawn that the illumination in accordance with suggested scheme has positive influence on productive and physiological qualities of replacement young laying hens. Negative effects of insufficient weight were avoided in both groups because in both groups the weight has reached the target value, however, in control group the weight was higher than target weight and it caused higher percentage of double-yolk eggs, higher need in feed, reduction of total number of eggs. 
Чирясов К.Г., Соломкин А.В., Морозов Е.И., Кошелев Д.А.

5. Коваленко О.Ю., Захаржевский О.А., Спирин А.А. Программное обеспечение для расчета облучательных установок. - Механизация и электрификация сельского хозяйства, 2006, № 9, с.14-15.

6. Пильщикова Ю.А., Коваленко О.Ю., Гусева Е.Д., Кудашкина М.В. Моделирование относительной спектральной чувствительности органа зрения биообъекта для оценки эффективности источников излучения. Современные проблемы науки и образования, 2014, № 4.

7. Руководство по содержанию родительского стада "Ross 308", Aviagen, 2008.

8. Пильщикова Ю.А., Коваленко О.Ю., Овчукова С.А. Влияние комбинированного излучения на молодняк птицы. - Вестник ФГОУ ВПО МГАУ, 2012, № 2, с.29-31.

9. Пильщикова Ю.А., Коваленко Е.А. Экономика и развитие облучательной техники. Сборник статей Международной научно-практической конференции "Инновационная наука и современное общество", 21-22 августа 2013 г. Часть 1, с.99-102.
Experiment 2. Day old cockerels from replacement young stock of Ross 308 cross were the study object. The special attention was paid to the control of body weight of cocks because they are inclined to fast weight gain. Physiological and reproductive qualities of cockerels depend on weight. Experiment results showed that for the whole period of growing $100 \%$ safety of young stock was observed only in experimental group; during all age periods the body weight of birds in experimental group reached the target value as opposed to the experimental group and it has significant value for the cockerels from parent stock. The study results are given in Table 2 .

The annual average economic effect per 300 animals is 722700 rubles. Calculations demonstrate that stock safety and uniformity allowed reducing the cost of production [10].

Thus, upon the use of the system of general illumination with standard luminescent lamps and local illumination and irradiation from blue-green light emitting diode clusters and ultraviolet lamps in developed lighting facility, the improvement of light and color environment in poultry house is provided, and this fact enhances the poultry productivity parameters and economical efficiency of use of lighting facilities. 